Article

\title{
Combining Dietary Sulfur Amino Acid Restriction with Polyunsaturated Fatty Acid Intake in Humans: A Randomized Controlled Pilot Trial
}

\author{
Thomas Olsen ${ }^{1, * \mathbb{C}}$, Bente Øvrebø ${ }^{1,2}$, Cheryl Turner ${ }^{3}$, Nasser E. Bastani ${ }^{1}$, Helga Refsum ${ }^{1}$ and \\ Kathrine J. Vinknes ${ }^{1}$ \\ 1 Department of Nutrition, Institute of Basic Medical Sciences, University of Oslo, 0372 Oslo, Norway; \\ benteov@me.com (B.Ø.); n.e.bastani@medisin.uio.no (N.E.B.); helga.refsum@medisin.uio.no (H.R.); \\ kathrine.vinknes@medisin.uio.no (K.J.V.) \\ 2 Øvrebø Nutrition, 0550 Oslo, Norway \\ 3 Department of Pharmacology, University of Oxford, Oxford OX1 3QT, UK; cheryl.turner@pharm.ox.ac.uk \\ * Correspondence: thomas.olsen@medisin.uio.no; Tel.: +47-406-24-230
}

Received: 22 October 2018; Accepted: 20 November 2018; Published: 23 November 2018

check for updates

\begin{abstract}
Dietary and plasma total cysteine (tCys) have been associated with adiposity, possibly through interaction with stearoyl-CoA desaturase (SCD), which is an enzyme that is involved in fatty acid and energy metabolism. We evaluated the effect of a dietary intervention with low cysteine and methionine and high polyunsaturated fatty acids (PUFAs) on plasma and urinary sulfur amino acids and SCD activity indices. Fourteen normal-weight healthy subjects were randomized to a seven-day diet low in cysteine and methionine and high in PUFAs (Cys/Met low $_{\text {low }}$ + PUFA), or high in saturated fatty acids (SFA), cysteine, and methionine (Cys/Met high $_{\text {S SFA). }}$ Compared with the Cys/Met $t_{\text {high }}+$ SFA group, plasma methionine and cystathionine decreased ( $p$-values $<0.05)$, whereas cystine tended to increase $(p=0.06)$ in the Cys/Met low + PUFA group. Plasma total cysteine (tCys) was not significantly different between the groups. Urinary cysteine and taurine decreased in the Cys/Met low $_{\text {low }}$ PUFA group compared with the Cys/Met high $_{\text {S SFA }}$ group ( $p$-values $<0.05$ ). Plasma SCD-activity indices were not different between the groups, but the change in cystine correlated with the SCD-16 index in the Cys/Met low $_{\text {low }}$ PUFA group. A diet low in methionine and cysteine decreased plasma methionine and urinary cysteine and taurine. Plasma tCys was unchanged, suggesting that compensatory mechanisms are activated during methionine and cysteine restriction to maintain plasma tCys.
\end{abstract}

Keywords: methionine; cysteine; amino acids; steaoryl-CoA desaturase; clinical trial

\section{Introduction}

There is increasing evidence on the importance of dietary protein in the regulation of metabolism and body adiposity, and a high habitual intake of predominantly animal protein is associated with increased adiposity in both cross-sectional and prospective studies [1-7]. This is consistent with human studies observing that plant-based diets are associated with the prevention of weight gain, type 2 diabetes, and cardiovascular disease $[6,8,9]$.

Methionine and cysteine are sulfur amino acids (SAAs) that are found in low amounts in plant foods and higher amounts in meats and fish [10]. Methionine is an essential amino acid that must be obtained from the diet, whereas cysteine is classified as conditionally essential, and can be obtained from the diet or synthesized endogenously from methionine metabolism [11,12]. More specifically, SAA metabolism includes the conversion of methionine to homocysteine through a sequence of 
reactions that are commonly termed transmethylation. Homocysteine can then undergo irreversible transsulfuration in the liver to form cystathionine and ultimately cysteine [11], which may be utilized in the synthesis of protein, taurine, or the antioxidant glutathione. Furthermore, cysteine is readily oxidized to form a dimer containing a disulfide bond between two cysteine molecules, cystine, or with other thiols (including thiols in protein), thereby forming cysteine mixed disulfides.

Total cysteine (tCys) refers to the sum of cysteine equivalents available after reduction of its oxidized forms. In plasma, it mainly consists of protein-bound cysteine, free cysteine-mixed disulfides, cysteine, and reduced cysteine (thiol form). Plasma concentrations of tCys have been strongly and positively associated with fat mass and obesity in several large epidemiological studies [13-15]. Moreover, results from studies examining the association of plasma SAAs with body mass index (BMI) and fat mass in children and adults $[14,16,17]$ suggest that these associations are mainly confined to tCys $[12,18]$.

The diet or drug-induced lowering of plasma tCys concentrations has been associated with beneficial changes in body composition in animal models [19-22], but the mechanisms through which cysteine promotes obesity is presently unknown. One possible mechanism may be by influencing the fatty acid desaturase enzyme stearoyl-CoA desaturase-1 (SCD1). In rodents, diets with low methionine/cysteine or excess cysteine respectively suppress or enhance hepatic Scd1 expression, plasma protein levels, and plasma SCD activity indices (fatty acid ratios of C16:1n-7/C16:0 and C18:1n-9/C18:0) [19,23]. Additionally, plasma tCys was positively associated with plasma SCD activity indices in two human populations [24]. Plasma SCD indices have previously been associated with obesity $[25,26]$, and $S c d 1$ expression is down-regulated by the intake of polyunsaturated fatty acids (PUFA) in mice $[27,28]$.

In this pilot study, we aimed to test a diet specifically developed for influencing SCD activity indices. We designed a diet low in methionine and cysteine and high in PUFAs and one diet high in methionine, cysteine and saturated fatty acids (SFA), and thus attempted to maximally influence SCD activity indices in plasma. The contents of cysteine and methionine in the two dietary interventions were set to reflect a diet profoundly restricted in SAAs (plant-based diet) versus a diet higher in protein (animal-based diet) [10]. We then compared the effect of a seven-day dietary intervention with contrasting contents of methionine and cysteine and PUFA on SAA concentrations in plasma and urine. Moreover, we assessed whether the diets influenced SCD activity indices in the plasma of healthy individuals, and whether changes in plasma SAAs were associated with the changes in SCD plasma activity indices.

\section{Materials and Methods}

\subsection{Participants}

In total, 14 participants were recruited online through the web and social media page of the University of Oslo. Since this was a pilot study, sample size was not calculated prior to trial commencement. Inclusion criteria were healthy normal-weight (BMI $20-25 \mathrm{~kg} / \mathrm{m}^{2}$ ) men and women, aged 20-40 years. Exclusion criteria were high intake of fatty fish or cod liver oil (fatty fish $\geq$ four times per week, cod liver oil, or n-3 fatty acid supplements $\geq$ three times every week), the use of medications, smoking (daily), the presence of major chronic disease, regular alcohol consumption (defined as $\geq$ four times per week), pregnancy, and breastfeeding. Written informed consent was obtained from all of the participants. The study protocol was approved by the Regional Committee for Medical Research Ethics South East and was registered with the United States (US) National Library of Medicine Clinical Trials registry (ClinicalTrials.gov Identifier: NCT02647970, registration date: 6 January 2016). All aspects of the study were conducted according to the Declaration of Helsinki. 


\subsection{Study Design and Outcomes}

The experimental protocol followed a randomized, parallel-design intervention trial among healthy volunteers. The trial consisted of a full diet intervention for seven days with follow-up visits at day three and day seven. The study was conducted at Centre for Clinical Nutrition at Institute of Basic Medical Sciences, University of Oslo (Oslo, Norway).

To ensure the similar distribution of men in each group, stratified block randomization with a block size of four was carried out using the "blockrand" package for R 3.0.2 (the R Foundation for Statistical Computing, Vienna, Austria) by study personnel. In total, 14 participants were randomized to one of two interventions either 1) rich in PUFA and low in cysteine and methionine (Cys/Met low $_{\text {low }}$ PUFA) $(n=7)$ or 2$)$ rich in SFA, cysteine, and methionine (Cys/Met ${ }_{\text {high }}+$ SFA) $(n=7)$. Primary outcomes were plasma SAAs and SCD activity, which was measured as plasma fatty acid product/precursor ratios.

One week before trial commencement, the participants were instructed to completely avoid intake of fatty fish, cod liver oil, n-3 fatty acid supplements, and other supplements, and consume only moderate amounts of alcohol (maximum two units three times per week). They were informed to keep their physical activity level normal, but avoid strenuous physical activity the day before the start of the study and during the intervention period. In addition, the subjects had to abstain from alcohol $24 \mathrm{~h}$ before the start of the study, and were instructed to eat a light meal low in fat after $18 \mathrm{~h}$, and not to eat anything eight hours before blood sampling at baseline.

\subsection{Dietary Interventions}

We developed a diet high in PUFA (n-3 and n-6 fatty acids) and low in SAAs and a control diet containing SFA and SAAs similar to a typical western diet. Cysteine and methionine are abundant in animal-derived protein, but also exist in certain fruits, grains, and vegetables; thus, both diets were vegan-based without meat, fish, eggs, dairy products, and certain plant-based foods, but included

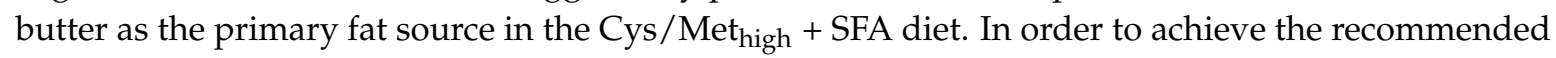
protein and micronutrient intake [29], all of the participants were given a powdered drink mix without SAAs (XMET XCYS Maxamaid ${ }^{\circledR}$ provided by Nutricia Norway AS, Oslo, Norway) that contained other essential and non-essential amino acids, carbohydrate, vitamins, minerals, and trace elements. Powdered SAAs (Jo Mar Laboratories, Scotts Valley, CA, USA) were added to the Cys/Met high $_{\text {+ SFA }}$ drink mix. Both diets also included n-3 supplements (Triomar ${ }^{\circledR}$ (Orkla Health Norge, Oslo, Norway) containing $1.32 \mathrm{~g}$ of $\mathrm{n}-3$ and Møllers Dobbel Kapse ${ }^{\circledR}$ (Orkla Health Norge, Oslo, Norway) containing $0.4 \mathrm{~g}$ of $\mathrm{n}-3$, vitamin A $(139 \mu \mathrm{g})$, vitamin D $(8.3 \mu \mathrm{g})$, and vitamin E (5.6 mg)). Meals were adapted to a Norwegian cuisine and available ingredients.

The supplements and foods were delivered to the home address of each participant, including a menu with recipes for each meal and information on daily intake. In an attempt to blind the participants to the intervention, the only difference between the two diets was the fat source used and the addition of SAAs to the powdered drink mix in the Cys / Met ${ }_{\text {high }}+$ SFA diet. A typical daily menu is outlined in Supplementary Table S1, and consisted of three main meals (breakfast, lunch, and dinner), one snack, and four glasses of juice mixed with the powdered drink mix. Both diets consisted of $100 \mathrm{~g} / \mathrm{d}$ of the powdered drink mix without SAAs. In the Cys/Met ${ }_{\text {high }}+$ SFA diet, a total of $4.8 \mathrm{~g}$ of SAAs ( $3.2 \mathrm{~g}$ cystine, $1.6 \mathrm{~g}$ methionine) were added to this amount. The participants were instructed to mix the powder with grape juice and drink it with each meal $(4 / \mathrm{d}, \sim 25 \mathrm{~g} / \mathrm{meal})$. The energy content of the diets was adapted to average gender requirements [29], and corresponded to $2000 \mathrm{kcal} / \mathrm{d}$ for women and $2500 \mathrm{kcal} / \mathrm{d}$ for men. The relative contribution of fat to the Cys/Met $\mathrm{Mw}_{\text {low }}$ + PUFA diet was 5.5 energy \% (E\%) SFA and 10.9 E\% PUFA (5.16 g n-3 and $18.3 \mathrm{~g} \mathrm{n}$-6) for women and $5.2 \mathrm{E} \% \mathrm{SFA}$ and $10.6 \mathrm{E} \%$ PUFA (5.86 $\mathrm{g} \mathrm{n}-3$ and $22.1 \mathrm{~g} \mathrm{n}-6$ ) for men. The total SAA content was $0.93 \mathrm{~g}$ for women and $1.19 \mathrm{~g}$ for men, which was considered restricted compared to a diet with higher protein

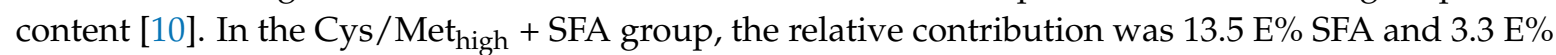
PUFA (1.5 g n-3 and $4.97 \mathrm{~g} \mathrm{n}-6$ ) for women, and 13.3 E\% SFA and 3.21 E\% PUFA (1.8 g n-3 and $6.17 \mathrm{~g}$ $\mathrm{n}-6)$ for men. The total SAA content was $5.75 \mathrm{~g}$ for women and $6.01 \mathrm{~g}$ for men, which is in line with a 
diet with higher protein content [10]. A detailed overview of the nutrient composition, including the SAA and fatty acid contents of the seven-day diet is presented in Supplementary Table S2. Participants were permitted to drink unlimited amounts of coffee, tea, water, and diet soda.

\subsection{Data Collection}

\subsubsection{Lifestyle and Dietary Data}

Data on health status and disease, the use of drugs, vitamins, or supplements, dietary habits, physical activity, cigarette smoking, alcohol consumption, and education were recorded using self-administered online questionnaires.

\subsubsection{Anthropometric Parameters}

A bioelectrical impedance weight (Seca mBCA515, Hamburg, Germany) was used to measure body weight and calculate BMI.

\subsection{Blood and Urine Sampling and Biochemical Assays}

\subsubsection{Blood Sampling}

Venous blood samples were collected from each participant at days 0 , three, and seven after an overnight fast. Blood from each participant was collected into three ethylenediaminetetetraacetic acid (EDTA)-lined vacuum tubes including one tube containing N-ethylmalemide (NEM) $150 \mathrm{mmol} / \mathrm{L}$ at $10 \%$ of the volume of the tube. NEM was used as a derivatization reagent to immediately trap the thiols [30]. Immediately after withdrawal, the blood was centrifuged for five minutes at $4{ }^{\circ} \mathrm{C}$. Plasma from the EDTA tubes without NEM were handled in two ways. (1) Aliquots of plasma were stored immediately at $-80{ }^{\circ} \mathrm{C}$ until analysis for total amino acids and fatty acids, and (2) aliquots were precipitated with 5-sulfosalicyclic acid (SSA) $10 \%$ to a final concentration of $5 \%$. The resultant supernatant was aliquoted and stored at $-80{ }^{\circ} \mathrm{C}$ until analysis of S-adenosylmethionine (SAM), S-adenosylhomocysteine (SAH), free homocysteine, cysteine, and glutathione. Plasma aliquots from the tubes containing both EDTA and NEM were also precipitated with SSA $10 \%$. The resultant supernatant was aliquoted and stored at $-80{ }^{\circ} \mathrm{C}$ until analysis of free oxidized and reduced homocysteine, cysteine, and glutathione.

\subsubsection{Urine Sampling}

Fasting morning urine samples were obtained at baseline, days three and seven. Urine samples were delivered in 100-mL cups and subsequently distributed in 9.5-mL tubes and frozen at $-80^{\circ} \mathrm{C}$ until analysis.

\subsubsection{Clinical Biochemistry}

Blood samples for the measurement of routine clinical biochemistry parameters were collected in EDTA-lined vacuum tubes and in gel tubes containing lithium heparin. Plasma concentrations of total cholesterol, low-density lipoprotein (LDL) cholesterol (LDL-C), high-density lipoprotein (HDL)-C, and triglycerides were measured at the Department of Medical Biochemistry (Oslo University Hospital Rikshospitalet, Oslo, Norway) by colorimetric and/or enzymatic methods on a Cobas c702 analyzer (Roche Diagnostics International Ltd., Rotkreuz, Switzerland).

\subsubsection{Amino Acid Assays}

Total (plasma and urine), free reduced/oxidized (plasma), and unbound (plasma) methionine, homocysteine, cysteine, cystathionine, taurine, and glutathione, as well as SAM and SAH, were measured by liquid chromatography-tandem mass spectrometry (LC-MS/MS). LC-MS/MS was performed using a Shimadzu LC-20ADXR Prominence LC system (Kyoto, Japan) coupled to a Sciex 
QTRAP5500 mass spectrometer with a Turbo V ion source and TurboIonspray probe (Framingham, MA, USA). The separation of the analytes was achieved using a Phenomenex Kinetex $2.6 \mu \mathrm{m}$ C18 $100 \mathrm{~A} 100 \times 4.6 \mathrm{~mm}$ column with an aqueous solution of formic acid $(0.5 \%)$ and heptafluorobutyric acid $(0.3 \%)$ and acetonitrile gradient mobile phase. Linear calibration curves of the peak area ratios of analytes and internal standards were used for quantification. Modified versions of previously described methods were used for total [31] and free reduced/oxidized forms [32] of amino acids as discussed briefly below.

For total plasma and urinary SAAs, isotopically labeled internal standards were added to plasma or urine followed by the reduction of disulfides using dithioerythritol (DTE) $100 \mathrm{mmol} / \mathrm{L}$, and then protein precipitation with SSA 10\%. The extracts were diluted with an aqueous solution of formic acid $[0.5 \%]$ and heptafluorobutyric acid $[0.3 \%]$ prior to analysis. Coefficients of variation for the analytes were 3.4-6.7\%. For plasma free reduced and oxidized cysteine and homocysteine, the NEM containing acidic plasma extracts were used. Cysteine-NEM, homocysteine-NEM, cysteine, and homocysteine were measured with isotopically labeled internal standards. Plasma SAM and SAH were measured from the acidic plasma extracts using isotopically labeled internal standards. The coefficients of variation for the analytes were $2-3 \%$. The acidic plasma extracts were also used to measure the unbound fraction. The acidic extracts were neutralized with ammonia $[0.25 \mathrm{~mol} / \mathrm{L}]$ prior to the addition of the reductant DTE. The total unbound fraction represents the combined free reduced and disulfide concentrations (including mixed disulfides). The coefficients of variation of the analytes were $4-6 \%$. The bound fraction was calculated by subtracting the unbound concentration from the total plasma concentration.

\subsubsection{Fatty Acid Assays}

Total plasma fatty acid concentrations were measured by gas chromatography-mass spectrometry (GC-MS) using a modified version of a previously described method [33]. The method involves the in situ transesterification of total lipid fatty acids from plasma into methyl esters. The fatty acid methyl esters (FAME) were analyzed by GC-MS. Briefly, methanolic hydrochloric acid ( $3 N$ ) was added to plasma and incubated in a water bath at $85^{\circ} \mathrm{C}$ for $1.5 \mathrm{~h}$. Heneicosanoic acid (C21:0) was used as an internal standard. Hexane containing butylated hydroxytoluene as an antioxidant was used for extraction. The hexane fraction containing FAME was analyzed using a Focus GC-DSQ II GC-MS system (Waltham, MA, USA) with an SGE GC column BPX70 $25 \mathrm{~m} \times 0.22 \mathrm{~mm}$, with 0.25- $\mu \mathrm{m}$ film (Victoria, Australia). Electron ionization positive mode selective ion monitoring was used for detection. Linear calibration curves of the peak area ratios of the analyte and internal standard were used for quantification. The coefficient of variation was 4.5-11.5\%. SCD indices were given as product/precursor-ratios of fatty acids in plasma (SCD-16; C16:1n-7/C16:0, SCD-18; C18:1n-9/C18:0).

\subsection{Statistical Analysis}

Data were presented as medians (range) for continuous variables and counts (\%) for categorical variables unless otherwise specified. Due to the small sample size and non-normal data distribution, we used non-parametric statistical tests for our main analyses. The Wilcoxon rank-sum test was used to assess between-group differences for continuous variables at baseline, and additionally at day three and day seven. Interventions were compared using linear mixed model regression (LMM). The models included group, time, and an interaction term for group and time as fixed effects. The interaction term was included in order to test for differences between groups depending on the time. Subjects were included as random effect variables to adjust for within-subject correlation. Due to the low number of participants, baseline differences occurred for plasma total homocysteine, reduced homocysteine, and homocysteine. These analyses were adjusted accordingly by including only group and the interaction term for group and time in the model for these parameters. The LMM approach provides several advantages over traditional repeated measures analysis of variance, as demonstrated elsewhere [34]. Results are expressed as estimated marginal means (EMMs) at 
each time point, and their corresponding 95\% confidence intervals were derived from each model. Simple linear regression was conducted to examine the relationship of SAAs with fatty acids and SCD activity indices. These analyses were conducted separately for each group or for the groups combined, adjusting for intervention allocation. The significance level was set to $p<0.05$. Statistical analyses were carried out using the "base" and "nlme" packages for the R (the R Foundation for Statistical Computing, Vienna, Austria) interface in the LabKey Server (Nelson EK, BMC Bioinformatics, 2011).

\section{Results}

\subsection{Baseline Characteristics}

Recruitment and completion of the trial was performed from May to November 2016. A flowchart outlining the study design and the flow of participants is presented in Figure 1. Baseline characteristics of the participants are presented in Table 1. Each group consisted of five women and two men. All of the randomized participants completed the trial. The groups were similar at baseline except

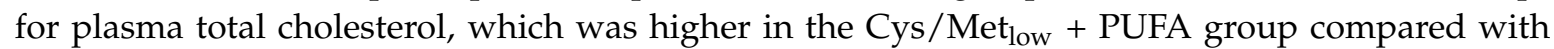

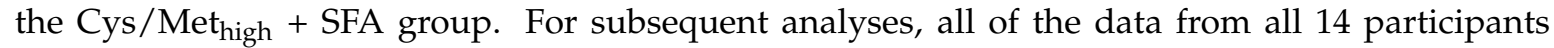
were available. Changes in baseline characteristics from day 0 to 7 are presented in Supplementary Table S3. Except for a trend for a greater reduction in total cholesterol in the Cys/Met low $_{\text {low }}$ PUFA

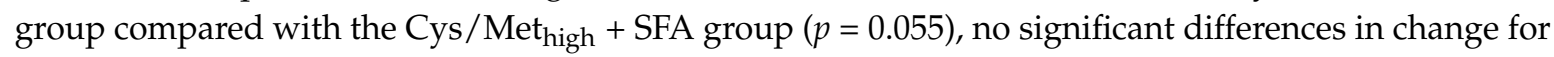
the baseline characteristics were observed.

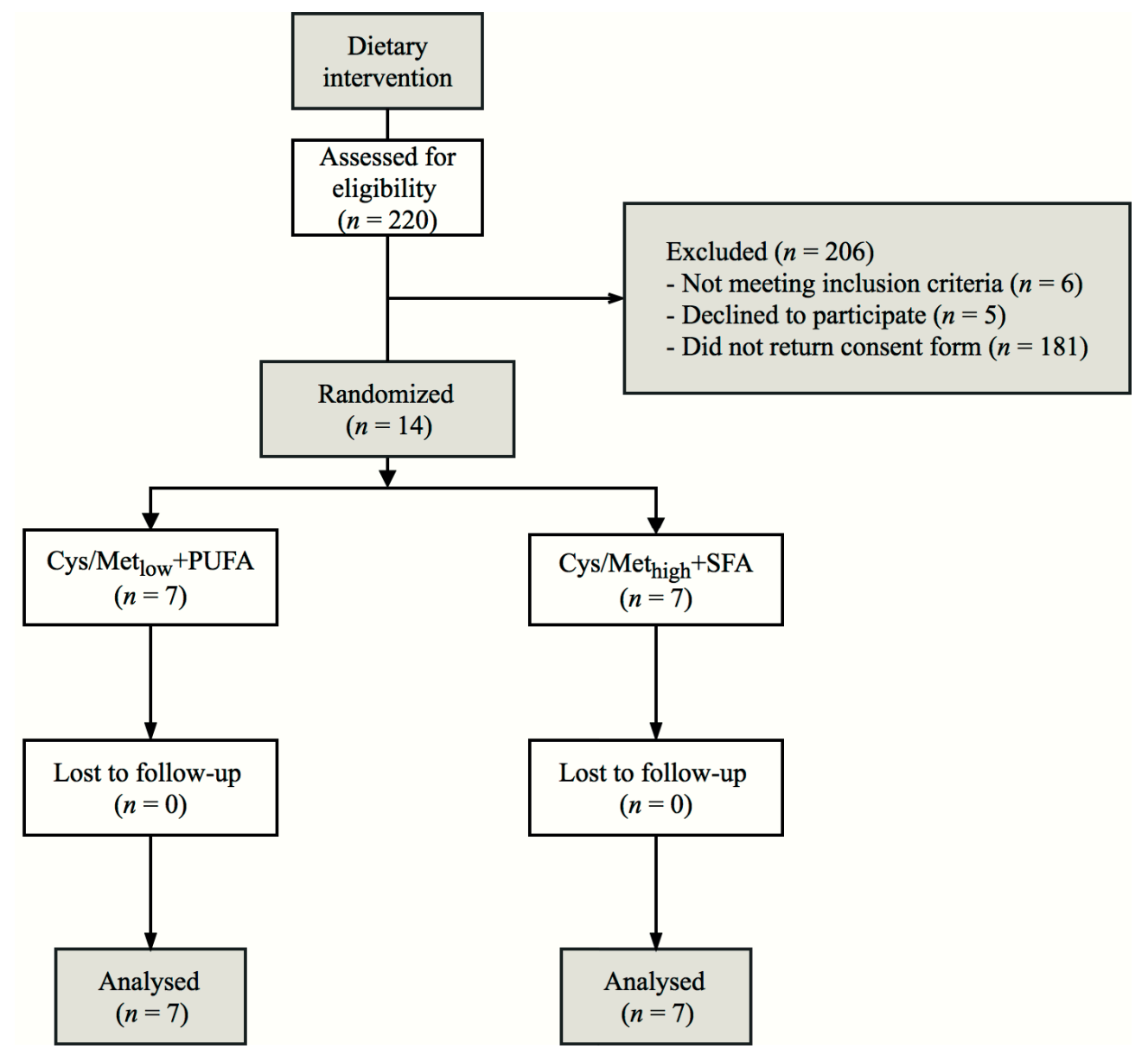

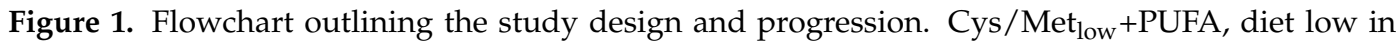
cysteine and methionine and high in polyunsaturated fatty acids; Cys/Met ${ }_{\text {high }}+\mathrm{SFA}$, diet high in cysteine, methionine and saturated fatty acids. 
Table 1. Characteristics of the study population

\begin{tabular}{cccc}
\hline & Cys/Met $_{\text {low }}+$ PUFA & Cys/Met $_{\text {high }}+$ SFA & $p$ \\
\hline Female, $\mathrm{n}$ & & & \\
Male, $\mathrm{n}$ & 5 & 5 & - \\
Age, $\mathrm{y}$ & 2 & 2 & - \\
Weight, $\mathrm{kg}$ & $31(20-37)$ & $24(21-38)$ & 0.70 \\
Height, m & $66.8(59.2-83.9)$ & $65.7(59.5-80.2)$ & 0.90 \\
BMI, kg/m ${ }^{2}$ & $1.71(1.66-1.89)$ & $1.73(1.59-1.84)$ & 0.75 \\
Total cholesterol, mmol/L & $22.6(21.1-25.0)$ & $22.3(20.7-26.2)$ & 1.00 \\
HDL cholesterol, mmol/L & $4.4(4.0-4.8)$ & $3.8(2.9-5.4)$ & 0.04 \\
LDL cholesterol, mmol/L & $1.6(1.3-2.1)$ & $1.5(1.2-2.3)$ & 0.84 \\
Triglycerides, mmol/L & $2.5(2.0-2.6)$ & $2.0(1.4-2.9)$ & 0.60 \\
\hline
\end{tabular}

Data are expressed as medians (range) or numbers. The Wilcoxon rank-sum test was used to assess between-group differences for continuous variables at baseline. Cys/Met ${ }_{\text {low }}+$ PUFA, diet low in cysteine and methionine and high in polyunsaturated fatty acids; Cys/Met ${ }_{\text {high }}+\mathrm{SFA}$, diet high in cysteine, methionine and saturated fatty acids; BMI, body mass index, HDL, high-density lipoprotein; LDL, low-density lipoprotein.

\subsection{Changes in Plasma SAAs in Response to the Dietary Interventions}

EMMs, their corresponding confidence intervals, and $p$-values for plasma concentrations of the SAAs at baseline, day three, and day seven are presented in Tables 2 and 3. We observed significant group $\times$ time interactions for methionine, $\mathrm{SAH}$, total homocysteine, and cystathionine. Overall, methionine and cystathionine decreased, whereas SAH and total homocysteine increased from baseline to day seven in the Cys/Met low $_{\text {PUFA group compared to the Cys/Met }}$ high + SFA group. We observed a trend for a group $\times$ time interaction for cysteine, which increased in the Cys $/ \mathrm{Met}_{\text {low }}+$ PUFA group compared to the Cys/Met $t_{\text {high }}+$ SFA group $(p=0.06)$.

\subsection{Changes in Urine SAAs in Response to the Dietary Interventions}

EMMs, their corresponding confidence intervals, and $p$-values for urinary SAAs at each visit are presented in Table 4 . We observed a significant group $\times$ time interaction for methionine, cysteine, and taurine, all of which were excreted to a lower extent in the Cys/Met low $_{\text {l }}$ PUFA group compared to the Cys/Met $t_{\text {high }}+$ SFA group after seven days.

\subsection{SCD Indices Based on Plasma Total Fatty Acids}

EMMs, their corresponding confidence intervals a $p$-values for C16:1n-7, C16:0, C18:1n-9, and C18:0, as well as SCD-16 and SCD-18, are presented in Supplementary Table S3. No significant interactions were observed following the dietary intervention for the fatty acids or SCD plasma indices.

\subsection{Associations between tCys Fractions and SCD Indices}

To further examine the relationship between SAAs and fatty acids, we performed simple linear regression to assess whether the change in tCys and its fractions were associated with changes in SCD activity indices. In a model adjusted for intervention allocation, change in cystine (standardized $\beta=0.72,95 \%$ CI: $0.25-1.20, p=0.014$ ) and reduced cysteine (standardized $\beta=0.59,95 \%$ CI: 0.10-1.10, $p=0.04$ ) was positively associated with the SCD-16 index. Similar results were observed only in the

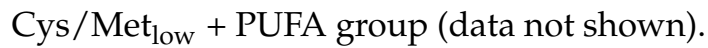

\subsection{Harmful Effects}

No harmful effects of the dietary interventions were reported. Two participants, one for each group, reported light gastrointestinal problems. 
Table 2. Estimated marginal means (95\% confidence interval) of plasma concentrations of amino acids and related metabolites.

\begin{tabular}{|c|c|c|c|c|c|}
\hline Amino Acids & Group & Baseline & Day 3 & Day 7 & $p_{\text {int }}$ \\
\hline \multirow[t]{2}{*}{ Methionine $^{1}$} & Cys/Met low $_{\text {low }}+$ PUFA & $\begin{array}{c}23.6 \\
(21.2,26)\end{array}$ & $\begin{array}{c}22.4 \\
(20.1,24.8)\end{array}$ & $\begin{array}{c}21.1 \\
(18.7,23.5)\end{array}$ & 0.044 \\
\hline & Cys/Met ${ }_{\text {high }}+$ SFA & $\begin{array}{c}22.2 \\
(19.8,24.6)\end{array}$ & $\begin{array}{c}21.8 \\
(19.5,24.2)\end{array}$ & $\begin{array}{c}23 \\
(20.6,25.3)\end{array}$ & \\
\hline \multirow[t]{2}{*}{ SAM $^{1}$} & Cys/Met low + PUFA & $\begin{array}{c}102 \\
(92.9,110)\end{array}$ & $\begin{array}{c}110 \\
(101,119)\end{array}$ & $\begin{array}{c}110 \\
(101,119)\end{array}$ & 0.27 \\
\hline & Cys/Met ${ }_{\text {high }}+$ SFA & $\begin{array}{c}104 \\
(95.3,113)\end{array}$ & $\begin{array}{c}100 \\
(91.8,109)\end{array}$ & $\begin{array}{c}105 \\
(95.9,113)\end{array}$ & \\
\hline \multirow[t]{2}{*}{$\mathrm{SAH}^{1}$} & Cys/Met low $_{\text {PUFA }}$ & $\begin{array}{c}12.8 \\
(8.8,16.8)\end{array}$ & $\begin{array}{c}14.2 \\
(10.2,18.2)\end{array}$ & $\begin{array}{c}14 \\
(10,18)\end{array}$ & $<0.01$ \\
\hline & Cys/Met ${ }_{\text {high }}+$ SFA & $\begin{array}{c}15.3 \\
(11.3,19.3)\end{array}$ & $\begin{array}{c}15.2 \\
(11.2,19.2)\end{array}$ & $\begin{array}{c}13.1 \\
(9.14,17.1)\end{array}$ & \\
\hline \multirow[t]{2}{*}{ SAM/SAH } & Cys $/$ Met $_{\text {low }}+$ PUFA & $\begin{array}{c}8.06 \\
(6.56,9.57)\end{array}$ & $\begin{array}{c}7.94 \\
(6.44,9.45)\end{array}$ & $\begin{array}{c}7.98 \\
(6.47,9.49)\end{array}$ & 0.25 \\
\hline & 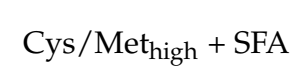 & $\begin{array}{c}7.8 \\
(6.29,9.3)\end{array}$ & $\begin{array}{c}7.6 \\
(6.1,9.11)\end{array}$ & $\begin{array}{c}8.42 \\
(6.91,9.92)\end{array}$ & \\
\hline \multirow[t]{2}{*}{$\mathrm{tHcy}^{1}$} & Cys/Met low $_{\text {PUFA }}$ & $\begin{array}{c}10.1 \\
(8.77,11.5)\end{array}$ & $\begin{array}{c}11.6 \\
(10.3,13)\end{array}$ & $\begin{array}{c}11.2 \\
(9.83,12.5)\end{array}$ & $<0.01$ \\
\hline & Cys/Met ${ }_{\text {high }}+$ SFA & $\begin{array}{c}6.79 \\
(5.44,8.14)\end{array}$ & $\begin{array}{c}6.44 \\
(5.09,7.79)\end{array}$ & $\begin{array}{c}6.28 \\
(4.93,7.63)\end{array}$ & \\
\hline \multirow[t]{2}{*}{ Cystathionine $^{2}$} & Cys $/$ Met $_{\text {low }}+$ PUFA & $\begin{array}{c}249 \\
(186,311)\end{array}$ & $\begin{array}{c}104 \\
(40.8,166)\end{array}$ & $\begin{array}{c}78.3 \\
(15.5,141)\end{array}$ & 0.041 \\
\hline & Cys/Met ${ }_{\text {high }}+$ SFA & $\begin{array}{c}110 \\
(46.7,172)\end{array}$ & $\begin{array}{c}117 \\
(53.8,179)\end{array}$ & $\begin{array}{c}126 \\
(63.4,189)\end{array}$ & \\
\hline \multirow[t]{2}{*}{ tCys ${ }^{1}$} & Cys $/$ Met $_{\text {low }}+$ PUFA & $\begin{array}{c}249 \\
(221,276)\end{array}$ & $\begin{array}{c}268 \\
(240,295)\end{array}$ & $\begin{array}{c}262 \\
(234,289)\end{array}$ & 0.35 \\
\hline & Cys/Met high $_{\text {+ SFA }}$ & $\begin{array}{c}241 \\
(214,269)\end{array}$ & $\begin{array}{c}251 \\
(223,278)\end{array}$ & $\begin{array}{c}246 \\
(218,273)\end{array}$ & \\
\hline \multirow[t]{2}{*}{$\mathrm{GSH}^{1}$} & Cys $/$ Met $_{\text {low }}+$ PUFA & $\begin{array}{c}5.5 \\
(4.75,6.25)\end{array}$ & $\begin{array}{c}6.29 \\
(5.54,7.04)\end{array}$ & $\begin{array}{c}4.91 \\
(4.16,5.66)\end{array}$ & 0.51 \\
\hline & Cys/Met ${ }_{\text {high }}+$ SFA & $\begin{array}{c}5.62 \\
(4.87,6.37)\end{array}$ & $\begin{array}{c}5.96 \\
(5.21,6.71)\end{array}$ & $\begin{array}{c}4.63 \\
(3.88,5.38)\end{array}$ & \\
\hline \multirow[t]{2}{*}{ Taurine $^{1}$} & Cys/Met low $_{\text {lo }}+$ PUFA & $\begin{array}{c}87.2 \\
(69.2,105)\end{array}$ & $\begin{array}{c}107 \\
(89.1,125)\end{array}$ & $\begin{array}{c}74.5 \\
(56.4,92.5)\end{array}$ & 0.46 \\
\hline & 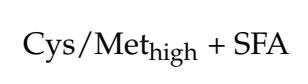 & $\begin{array}{c}77.5 \\
(59.5,95.6)\end{array}$ & $\begin{array}{c}82.4 \\
(64.4,100)\end{array}$ & $\begin{array}{c}75.7 \\
(57.6,93.7)\end{array}$ & \\
\hline
\end{tabular}

Estimated marginal means and their $95 \%$ confidence intervals of amino acids at baseline, day three, and day seven in diet interventions. $p$-values are computed using linear mixed model regression with group, time, and group $\times$ time interaction term in the model. Cys $/ \mathrm{Met}_{\text {low }}+\mathrm{PUFA}$, diet low in cysteine and methionine and high in polyunsaturated fatty acids; Cys $/ \mathrm{Met}_{\text {high }}+\mathrm{SFA}$, diet high in cysteine, methionine and saturated fatty acids; $p_{\text {int }}$, $p$-value for group $\times$ time interaction. Abbreviations: SAM, S-adenosylmethionine; $\mathrm{SAH}, \mathrm{S}$-adenosylhomocysteine; $\mathrm{tHcy}$, total homocysteine; tCys, total cysteine; GSH, total glutathione. ${ }^{1}$ Values expressed as $\mu \mathrm{mol} / \mathrm{L} ;{ }^{2}$ values expressed as $\mathrm{nmol} / \mathrm{L}$. 
Table 3. Estimated marginal means (95\% confidence interval) of fractions of total homocysteine and total cysteine in plasma.

\begin{tabular}{|c|c|c|c|c|c|}
\hline Amino Acids & Group & Baseline & Day 3 & Day 7 & $p_{\text {int }}$ \\
\hline \multirow[t]{2}{*}{ Free hcy ${ }^{1}$} & Cys/Met ${ }_{\text {low }}+$ PUFA & $\begin{array}{c}2.77 \\
(2.47,3.08)\end{array}$ & $\begin{array}{c}3.00 \\
(2.70,3.31)\end{array}$ & $\begin{array}{c}2.95 \\
(2.64,3.26)\end{array}$ & 0.023 \\
\hline & Cys/Met high $_{\text {SFA }}$ & $\begin{array}{c}1.96 \\
(1.66,2.27)\end{array}$ & $\begin{array}{c}1.83 \\
(1.52,2.14)\end{array}$ & $\begin{array}{c}1.89 \\
(1.58,2.2)\end{array}$ & \\
\hline \multirow[t]{2}{*}{ Protein-bound hcy ${ }^{1}$} & Cys/Met ${ }_{\text {low }}+$ PUFA & $\begin{array}{c}7.34 \\
(6.25,8.43)\end{array}$ & $\begin{array}{c}8.61 \\
(7.53,9.7)\end{array}$ & $\begin{array}{c}8.23 \\
(7.14,9.31)\end{array}$ & $<0.01$ \\
\hline & Cys/Met high $_{\text {SFA }}$ & $\begin{array}{c}4.82 \\
(3.74,5.91)\end{array}$ & $\begin{array}{c}4.61 \\
(3.52,5.7)\end{array}$ & $\begin{array}{c}4.39 \\
(3.3,5.48)\end{array}$ & \\
\hline \multirow[t]{2}{*}{ Red hcy ${ }^{2}$} & Cys/Met low $_{\text {PUFA }}$ & $\begin{array}{c}141 \\
(93,189)\end{array}$ & $\begin{array}{c}156 \\
(108,204)\end{array}$ & $\begin{array}{c}184 \\
(134,234)\end{array}$ & 0.29 \\
\hline & Cys/Met high $_{\text {SFA }}$ & $\begin{array}{c}172 \\
(124,220)\end{array}$ & $\begin{array}{c}136 \\
(88.3,184)\end{array}$ & $\begin{array}{c}174 \\
(126,222)\end{array}$ & \\
\hline \multirow[t]{2}{*}{ Homocystine $^{2}$} & Cys/Met ${ }_{\text {low }}+$ PUFA & $\begin{array}{c}22.9 \\
(17.7,28.2)\end{array}$ & $\begin{array}{c}30.3 \\
(25.1,35.6)\end{array}$ & $\begin{array}{c}29.6 \\
(24.1,35.1)\end{array}$ & $<0.01$ \\
\hline & Cys/Met high $_{\text {SFA }}$ & $\begin{array}{c}12.8 \\
(7.49,18)\end{array}$ & $\begin{array}{c}11.4 \\
(6.09,16.6)\end{array}$ & $\begin{array}{c}11.3 \\
(6.08,16.6)\end{array}$ & \\
\hline \multirow[t]{2}{*}{$\begin{array}{c}\text { Reduced } \\
\text { hcy/homocystine }\end{array}$} & Cys/Met ${ }_{\text {low }}+$ PUFA & $\begin{array}{c}6.71 \\
(3.48,9.95) \\
\end{array}$ & $\begin{array}{c}5.5 \\
(2.27,8.74) \\
\end{array}$ & $\begin{array}{c}6.5 \\
(3.12,9.88) \\
\end{array}$ & 0.48 \\
\hline & 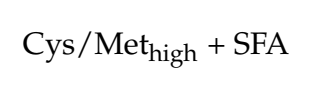 & $\begin{array}{c}14.1 \\
(10.9,17.4)\end{array}$ & $\begin{array}{c}11.8 \\
(8.57,15)\end{array}$ & $\begin{array}{c}15.6 \\
(12.4,18.8)\end{array}$ & \\
\hline \multirow[t]{2}{*}{ Free cysteine ${ }^{1}$} & Cys/Met ${ }_{\text {low }}+$ PUFA & $\begin{array}{c}118 \\
(106,131)\end{array}$ & $\begin{array}{c}121 \\
(108,134)\end{array}$ & $\begin{array}{c}122 \\
(109,134)\end{array}$ & 0.55 \\
\hline & 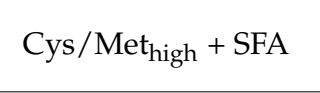 & $\begin{array}{c}115 \\
(102,128)\end{array}$ & $\begin{array}{c}116 \\
(103,129)\end{array}$ & $\begin{array}{c}121 \\
(108,134)\end{array}$ & \\
\hline \multirow[t]{2}{*}{$\begin{array}{l}\text { Protein-bound } \\
\text { cysteine }^{1}\end{array}$} & Cys/Met ${ }_{\text {low }}+$ PUFA & $\begin{array}{c}130 \\
(114,147)\end{array}$ & $\begin{array}{c}147 \\
(130,163)\end{array}$ & $\begin{array}{c}140 \\
(124,157)\end{array}$ & 0.21 \\
\hline & Cys/Met ${ }_{\text {high }}+$ SFA & $\begin{array}{c}126 \\
(110,143)\end{array}$ & $\begin{array}{c}135 \\
(118,151)\end{array}$ & $\begin{array}{c}125 \\
(108,141)\end{array}$ & \\
\hline \multirow[t]{2}{*}{ Reduced cysteine $^{1}$} & Cys/Met ${ }_{\text {low }}+$ PUFA & $\begin{array}{c}10.1 \\
(8.44,11.8)\end{array}$ & $\begin{array}{c}9.65 \\
(7.96,11.3)\end{array}$ & $\begin{array}{c}10.2 \\
(8.46,12)\end{array}$ & 0.42 \\
\hline & Cys/Met high $_{\text {SFA }}$ & $\begin{array}{c}12.5 \\
(10.8,14.2) \\
\end{array}$ & $\begin{array}{c}11.2 \\
(9.55,12.9) \\
\end{array}$ & $\begin{array}{c}13.7 \\
(12,15.4)\end{array}$ & \\
\hline \multirow[t]{2}{*}{ Cystine $^{1}$} & Cys/Met ${ }_{\text {low }}+$ PUFA & $\begin{array}{c}35.5 \\
(30.8,40.1)\end{array}$ & $\begin{array}{c}37.4 \\
(32.7,42)\end{array}$ & $\begin{array}{c}39 \\
(34.2,43.8)\end{array}$ & 0.06 \\
\hline & Cys/Met ${ }_{\text {high }}+$ SFA & $\begin{array}{c}36.1 \\
(31.5,40.8)\end{array}$ & $\begin{array}{c}36.7 \\
(32.1,41.4)\end{array}$ & $\begin{array}{c}35.5 \\
(30.8,40.2)\end{array}$ & \\
\hline \multirow[t]{2}{*}{$\begin{array}{c}\text { Reduced } \\
\text { cysteine/cystine }\end{array}$} & Cys/Met ${ }_{\text {low }}+$ PUFA & $\begin{array}{c}0.291 \\
(0.24,0.34)\end{array}$ & $\begin{array}{c}0.262 \\
(0.21,0.31)\end{array}$ & $\begin{array}{c}0.265 \\
(0.21,0.32)\end{array}$ & 0.07 \\
\hline & Cys/Met high $_{\text {SFA }}$ & $\begin{array}{c}0.348 \\
(0.30,0.40)\end{array}$ & $\begin{array}{c}0.31 \\
(0.26,0.36)\end{array}$ & $\begin{array}{c}0.389 \\
(0.34,0.44)\end{array}$ & \\
\hline
\end{tabular}

Estimated marginal means and their $95 \%$ confidence intervals of homocysteine, cysteine and glutathione at baseline, day three, and day. $p$-values are computed using linear mixed model regression with group, time, and group $\times$ time interaction term in the model. Cys/Met low $_{1}+\mathrm{PUFA}$, diet low in cysteine and methionine and high in polyunsaturated fatty acids; Cys/ Met $_{\text {high }}+\mathrm{SFA}$, diet high in cysteine, methionine and saturated fatty acids; $p_{\text {int }}, p$-value for group $\times$ time interaction. Hcy, homocysteine; ${ }^{1}$ Values expressed as $\mu \mathrm{mol} / \mathrm{L} ;{ }^{2}$ values expressed as $\mathrm{nmol} / \mathrm{L}$. 
Table 4. Estimated marginal means (95\% confidence interval) of urinary concentrations of amino acids and related metabolites.

\begin{tabular}{|c|c|c|c|c|c|}
\hline \multicolumn{2}{|c|}{ Amino Acids, $\mu \mathrm{mol} / \mathrm{mmol}$ Creatinine } & \multirow{2}{*}{$\begin{array}{c}\text { Baseline } \\
0.83 \\
(0.63,1.04)\end{array}$} & \multirow{2}{*}{$\begin{array}{c}\text { Day } 3 \\
0.44 \\
(0.20,0.67)\end{array}$} & \multirow{2}{*}{$\begin{array}{c}\text { Day } 7 \\
0.38 \\
(0.18,0.58)\end{array}$} & \multirow{2}{*}{$\begin{array}{l}p_{\text {int }} \\
0.047\end{array}$} \\
\hline Methionine & Cys/Met ${ }_{\text {low }}+$ PUFA & & & & \\
\hline & Cys/Met high $_{\text {SFA }}$ & $\begin{array}{c}0.80 \\
(0.60,1.00)\end{array}$ & $\begin{array}{c}0.65 \\
(0.45,0.85)\end{array}$ & $\begin{array}{c}0.73 \\
(0.53,0.93)\end{array}$ & \\
\hline \multirow[t]{2}{*}{ tHcy } & Cys/Met ${ }_{\text {low }}+$ PUFA & $\begin{array}{c}0.31 \\
(0.17,0.45)\end{array}$ & $\begin{array}{c}0.34 \\
(0.18,0.52)\end{array}$ & $\begin{array}{c}0.29 \\
(0.16,0.43)\end{array}$ & 0.316 \\
\hline & Cys/Met high $_{\text {S SFA }}$ & $\begin{array}{c}0.22 \\
(0.09,0.36)\end{array}$ & $\begin{array}{c}0.32 \\
(0.19,0.46)\end{array}$ & $\begin{array}{c}0.33 \\
(0.19,0.46)\end{array}$ & \\
\hline \multirow[t]{2}{*}{ Cystathionine } & Cys/Met ${ }_{\text {low }}+$ PUFA & $\begin{array}{c}4.27 \\
(2.72,5.81)\end{array}$ & $\begin{array}{c}0.18 \\
(-1.65,2.01)\end{array}$ & $\begin{array}{c}0.182 \\
(-1.37,1.73)\end{array}$ & 0.043 \\
\hline & Cys/Met ${ }_{\text {high }}+$ SFA & $\begin{array}{c}0.86 \\
(-0.68,2.42)\end{array}$ & $\begin{array}{c}0.68 \\
(-0.86,2.24)\end{array}$ & $\begin{array}{c}0.93 \\
(-0.61,2.48)\end{array}$ & \\
\hline \multirow[t]{2}{*}{ tCys } & Cys/Met ${ }_{\text {low }}+$ PUFA & $\begin{array}{c}21.2 \\
(16.2,26.2)\end{array}$ & $\begin{array}{c}18.1 \\
(12.5,23.6)\end{array}$ & $\begin{array}{c}17.9 \\
(12.9,22.9)\end{array}$ & 0.001 \\
\hline & Cys/Met high $_{\text {SFA }}$ & $\begin{array}{c}21.1 \\
(16.1,26.1) \\
\end{array}$ & $\begin{array}{c}30.4 \\
(25.4,35.4) \\
\end{array}$ & $\begin{array}{c}32.2 \\
(27.2,37.2) \\
\end{array}$ & \\
\hline \multirow[t]{2}{*}{ Glutathione } & Cys/Met low $_{\text {lo }}+$ PUFA & $\begin{array}{c}0.12 \\
(0.06,0.18)\end{array}$ & $\begin{array}{c}0.10 \\
(0.03,0.17)\end{array}$ & $\begin{array}{c}0.09 \\
(0.03,0.15)\end{array}$ & 0.786 \\
\hline & 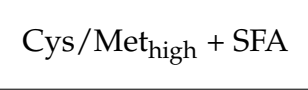 & $\begin{array}{c}0.21 \\
(0.15,0.27)\end{array}$ & $\begin{array}{c}0.21 \\
(0.15,0.27) \\
\end{array}$ & $\begin{array}{c}0.17 \\
(0.11,0.22) \\
\end{array}$ & \\
\hline \multirow[t]{2}{*}{ Taurine } & Cys/Met ${ }_{\text {low }}+$ PUFA & $\begin{array}{c}42.6 \\
(23.8,61.3)\end{array}$ & $\begin{array}{c}23.8 \\
(2.28,45.4)\end{array}$ & $\begin{array}{c}8.72 \\
(-10.0,27.5)\end{array}$ & 0.009 \\
\hline & Cys/Met high $_{\text {SFA }}$ & $\begin{array}{c}15.9 \\
(-2.81,34.7)\end{array}$ & $\begin{array}{c}19.9 \\
(1.12,38.6)\end{array}$ & $\begin{array}{c}23.6 \\
(4.82,42.3)\end{array}$ & \\
\hline
\end{tabular}

Estimated marginal means and their $95 \%$ confidence intervals of creatinine adjusted urinary concentrations amino acids at baseline, day three, and day seven in diet interventions with low methionine and cysteine and high PUFA, or high methionine, cysteine, and SFA. $p$-values are computed using linear mixed model regression with group, time, and group $\times$ time interaction terms in the model. Cys/Met low $+\mathrm{PUFA}$, diet low in cysteine and methionine and

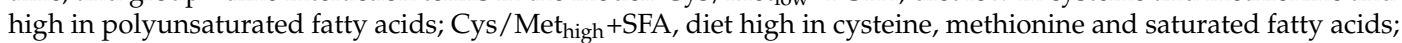
$p_{\text {int }}, p$-value for group $\times$ time interaction. tHcy, total homocysteine; tCys, total cysteine.

\section{Discussion}

In this randomized clinical trial and pilot study, we demonstrated effects of a seven-day diet rich in PUFA and restricted in methionine and cysteine on plasma and urinary concentrations of SAA and related products from SAA metabolism.

To our knowledge, this is the first study to address the effects of combined SAA restriction and PUFA enrichment on plasma concentrations of SAAs and fatty acids. We observed no significant differences in plasma tCys between the Cys/Met low $_{\text {l PUFA and Cys/Met }}$ high + SFA group. However, there was a somewhat surprising but clear trend for an increase in plasma cystine and reduced cysteine, which are important fractions of tCys [30], in the Cys/Met low $_{\text {PUFA compared to the Cys/Met }}$ high + SFA group. Although there are other studies on diets where SAA intake was manipulated [35-37], our results are not directly comparable due to methodological differences such as differing contents of protein and SAA in the diets. However, one study that examined the effects of dietary SAA depletion on fasting plasma cysteine concentrations showed decreased plasma free cysteine concentrations, but no change in free cystine after four days of SAA depletion [38]. The absent effect of SAA restriction on plasma tCys in our study, and the trend for increased cystine concentrations, suggest that compensatory mechanisms are activated when dietary methionine and cysteine are limited. In particular, the enzyme cysteine dioxygenase, which catalyzes the irreversible two-step conversion of cysteine to taurine, 
possesses negligible activity in rats fed an SAA-deficient diet, and is considered essential for the maintenance of plasma tCys and sulfur availability $[39,40]$. We also demonstrated a significant decline in the urinary excretion of cysteine in the Cys / Met low $_{\text {PUFA group compared to the Cys/Met }}$ high + SFA group in which excretion increased considerably. This is in line with a previous study that demonstrated decreased urinary sulfate excretion following protein restriction when comparing diabetics to healthy controls [41]. Thus, we speculate that compensatory mechanisms resulted in increased plasma cystine concentrations and a lower urinary output of tCys, indicating that urinary $\mathrm{tCys}$ excretion may be a more suitable marker for dietary cysteine restriction compared to plasma tCys. However, the relevance of this particular finding is unclear, and should be addressed further as it is not known whether urinary $\mathrm{tCys}$ resembles plasma $\mathrm{tCys}$ in its association with adverse outcomes.

We observed an increase in plasma homocysteine in the Cys/Met low $_{\text {PUFA group compared }}$ to the Cys $/$ Met $_{\text {high }}+$ SFA group. The increase in homocysteine could be explained by the allosteric regulation of cystathionine- $\beta$-synthase by SAM, resulting in the inhibition of transsulfuration and thereby increased homocysteine concentrations available for homocysteine remethylation to methionine. Although circulating homocysteine has been recognized as a risk factor for cardiovascular disease [42], the increase in the Cys / Met ${ }_{\text {low }}+$ PUFA group possibly reflects a homeostatic response to maintain plasma methionine in order to conserve methionine for protein synthesis and SAM production [43]. SAM is the primary methyl group donor in the majority of biological methylation reactions, including DNA methylation. The product of these methylation reactions is $\mathrm{SAH}$, which is a potent inhibitor of transmethylations, and the ratio of SAM/SAH is regarded as the measure of methylation capacity [44]. Interestingly, SAH was increased in the Cys/Met low + PUFA group compared to the Cys $/$ Met $_{\text {high }}+$ SFA group. Both deficient and excess methionine intake can impact the methionine cycle, resulting in alterations of SAM, SAH, and homocysteine concentrations, with a possible impact on DNA methylation and consequently gene expression.

The dietary intervention did not affect plasma indices of SCD-16 or SCD-18. However, we observed a positive association between the change in cystine and reduced cysteine and the change in the SCD-16 index from baseline to day seven in the Cys / Met ${ }_{\text {low }}+$ PUFA group. Animal studies have shown that cysteine affects SCD expression in the liver [19,23], and a positive association between tCys and SCD has been demonstrated in human populations [24]. This finding indicates that cysteine restriction induces cysteine-sparing effects, which in turn may affect plasma SCD activity indices. Future studies should address whether this effect is present in interventions with SAA restriction beyond one week.

The strengths of this study include the randomized, controlled design of the intervention and a well-balanced diet independent of the interventions. Moreover, although we did not manage to fully blind the different tastes of the interventions, the only differing foodstuffs between the diets was the oil/butter used as fat sources in some of the meals, and the powdered methionine and cysteine supplied in the drink mix of the participants in the SFA + Cys/Met group. The level of

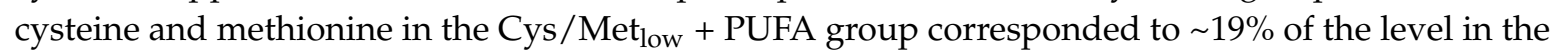
Cys/Met ${ }_{\text {high }}+$ SFA group. In comparison, a common methionine-restricted diet in rodents is deficient in cysteine and contains a methionine level of $\sim 20 \%$ relative to the control group [45]. This study also has several limitations, including a small sample size and short observation period, and it is possible that the null effect on plasma concentrations of tCys and SCD, as well as the increase in cysteine was influenced by the short intervention period. One 16-week study in overweight individuals managed to lower cysteine [46], and the trend for an increase that we observed may be transient and reflect short-term compensatory mechanisms. Considering that SCD is normally responsive to PUFA intake in humans [47-49], we cannot exclude the possibility that the recruited individuals were already eating high amounts of PUFAs. Although we excluded participants with very high intakes of PUFA-rich foods or supplements, the intervention may thus not have been intensive enough to induce a response in plasma. The diet was created to maximize the effects on SCD activity indices; however, we acknowledge that a factorial $2 \times 2$ design may be preferable to the current design, as the 
effects of methionine and cysteine restriction cannot be distinguished from the increased PUFA content. Thus, future investigations should be of longer term and with careful selection of an appropriate study population, and the intervention design should be reconsidered. Finally, there were relatively large baseline differences in some of the metabolites, including homocysteine, which may be attributed to unfortunate randomization. We attempted to adjust for baseline differences in the analyses, but cannot exclude the possibility of additional confounding introduced by errors in the randomization protocol.

We show that plasma methionine and cystathionine, and urinary cysteine and taurine were decreased, whereas plasma cysteine and markers of SCD activity were not affected following a seven-day diet low in methionine and cysteine. Future studies should assess the potential compensatory mechanisms in response to SAA restriction, and whether these findings have implications for clinical end points. Furthermore, urinary levels of cysteine and taurine should be further investigated as potential biomarkers for dietary SAA intake. In order to establish the clinical implications of a diet low in SAA and high in PUFA, future studies should assess its effects in an overweight or obese population in which SAA and SCD1 activity indices are likely to be higher, possibly reflecting a disrupted metabolism of these compounds.

Supplementary Materials: The following are available online at http:/ /www.mdpi.com/2072-6643/10/12/1822/s1, Table S1: A typical daily menu in the 7-day diet; Table S2: Average nutrient content and composition in the 7-day diet for each intervention group; Table S3: Change from baseline in metabolic parameters; Table S4: Fatty acids and SCD activity indices

Author Contributions: Conceptualization, B.Ø., H.R. and K.J.V.; Data curation, T.O.; Formal analysis, T.O. and K.J.V.; Investigation, T.O., C.T., N.E.B. and K.J.V.; Methodology, C.T. and N.E.B.; Project administration, H.R. and K.J.V.; Writing-original draft, T.O., B.Ø., C.T., N.E.B., H.R. and K.J.V.; Writing-review \& editing, T.O., B.Ø., C.T., N.E.B., H.R. and K.J.V.

Funding: This study has received support from The Research Council of Norway and University of Oslo, Norway.

Acknowledgments: The authors sincerely thank Anne-Randi Enget, Cynthia Prendergast, Kristin Lærkerød and Kristin Sandnes for assistance with handling and preparation of blood and urine samples; Proteinfabrikken for the provision of shakers; Kari Holte for practical organization at the study center; and all study participants for their time.

Conflicts of Interest: The authors declare that they have no conflict of interest.

Data availability statement: Raw data material and protocol will be made available upon request to the authors.

\section{References}

1. Koppes, L.L.; Boon, N.; Nooyens, A.C.; van Mechelen, W.; Saris, W.H. Macronutrient distribution over a period of 23 years in relation to energy intake and body fatness. Br. J. Nutr. 2009, 101, 108-115. [CrossRef] [PubMed]

2. Murtaugh, M.A.; Herrick, J.S.; Sweeney, C.; Baumgartner, K.B.; Guiliano, A.R.; Byers, T.; Slattery, M.L. Diet composition and risk of overweight and obesity in women living in the southwestern United States. J. Am. Diet. Assoc. 2007, 107, 1311-1321. [CrossRef] [PubMed]

3. Silventoinen, K.; Hasselbalch, A.L.; Lallukka, T.; Bogl, L.; Pietilainen, K.H.; Heitmann, B.L.; Schousboe, K.; Rissanen, A.; Kyvik, K.O.; Sorensen, T.I.; et al. Modification effects of physical activity and protein intake on heritability of body size and composition. Am. J. Clin. Nutr. 2009, 90, 1096-1103. [CrossRef] [PubMed]

4. Vinknes, K.J.; de Vogel, S.; Elshorbagy, A.K.; Nurk, E.; Drevon, C.A.; Gjesdal, C.G.; Tell, G.S.; Vollset, S.E.; Refsum, H. Dietary intake of protein is positively associated with percent body fat in middle-aged and older adults. J. Nutr. 2011, 141, 440-446. [CrossRef] [PubMed]

5. Bujnowski, D.; Xun, P.; Daviglus, M.L.; Van Horn, L.; He, K.; Stamler, J. Longitudinal association between animal and vegetable protein intake and obesity among men in the United States: The Chicago Western Electric Study. J. Am. Diet. Assoc. 2011, 111, 1150-1155. [CrossRef] [PubMed]

6. Rosell, M.; Appleby, P.; Spencer, E.; Key, T. Weight gain over 5 years in 21,966 meat-eating, fish-eating, vegetarian, and vegan men and women in EPIC-Oxford. Int. J. Obes. (Lond.) 2006, 30, 1389-1396. [CrossRef] [PubMed] 
7. Spencer, E.A.; Appleby, P.N.; Davey, G.K.; Key, T.J. Diet and body mass index in 38000 EPIC-Oxford meat-eaters, fish-eaters, vegetarians and vegans. Int. J. Obes. Relat. Metab. Disord. 2003, 27, 728-734. [CrossRef] [PubMed]

8. Velasquez, M.T.; Bhathena, S.J. Role of dietary soy protein in obesity. Int. J. Med. Sci. 2007, 4, 72-82. [CrossRef] [PubMed]

9. McMacken, M.; Shah, S. A plant-based diet for the prevention and treatment of type 2 diabetes. J. Geriatr. Cardiol. 2017, 14, 342-354. [PubMed]

10. Nimni, M.E.; Han, B.; Cordoba, F. Are we getting enough sulfur in our diet? Nutr. Metab. 2007, 4, 24. [CrossRef] [PubMed]

11. Brosnan, J.T.; Brosnan, M.E. The sulfur-containing amino acids: An overview. J. Nutr. 2006, 136, 1636S-1640S. [CrossRef] [PubMed]

12. Elshorbagy, A.K.; Smith, A.D.; Kozich, V.; Refsum, H. Cysteine and obesity. Obesity 2012, $20,473-481$. [CrossRef] [PubMed]

13. El-Khairy, L.; Ueland, P.M.; Nygard, O.; Refsum, H.; Vollset, S.E. Lifestyle and cardiovascular disease risk factors as determinants of total cysteine in plasma: The Hordaland Homocysteine Study. Am. J. Clin. Nutr. 1999, 70, 1016-1024. [CrossRef] [PubMed]

14. Elshorbagy, A.K.; Nurk, E.; Gjesdal, C.G.; Tell, G.S.; Ueland, P.M.; Nygard, O.; Tverdal, A.; Vollset, S.E.; Refsum, H. Homocysteine, cysteine, and body composition in the Hordaland Homocysteine Study: Does cysteine link amino acid and lipid metabolism? Am. J. Clin. Nutr. 2008, 88, 738-746. [CrossRef] [PubMed]

15. Elshorbagy, A.K.; Refsum, H.; Smith, A.D.; Graham, I.M. The association of plasma cysteine and gamma-glutamyltransferase with BMI and obesity. Obesity 2009, 17, 1435-1440. [PubMed]

16. Elshorbagy, A.K.; Valdivia-Garcia, M.; Graham, I.M.; Palma Reis, R.; Sales Luis, A.; Smith, A.D.; Refsum, H. The association of fasting plasma sulfur-containing compounds with BMI, serum lipids and apolipoproteins. Nutr. Metab. Cardiovasc. Dis. 2012, 22, 1031-1038. [CrossRef] [PubMed]

17. Elshorbagy, A.K.; Valdivia-Garcia, M.; Refsum, H.; Butte, N. The association of cysteine with obesity, inflammatory cytokines and insulin resistance in Hispanic children and adolescents. PLOS ONE 2012, 7, e44166. [CrossRef] [PubMed]

18. Elshorbagy, A.K.; Kozich, V.; Smith, A.D.; Refsum, H. Cysteine and obesity: Consistency of the evidence across epidemiologic, animal and cellular studies. Curr. Opin. Clin. Nutr. Metab. Care 2012, 15, 49-57. [CrossRef] [PubMed]

19. Elshorbagy, A.K.; Valdivia-Garcia, M.; Mattocks, D.A.; Plummer, J.D.; Smith, A.D.; Drevon, C.A.; Refsum, H.; Perrone, C.E. Cysteine supplementation reverses methionine restriction effects on rat adiposity: Significance of stearoyl-coenzyme A desaturase. J. Lipid Res. 2011, 52, 104-112. [CrossRef] [PubMed]

20. Elshorbagy, A.K.; Valdivia-Garcia, M.; Refsum, H.; Smith, A.D.; Mattocks, D.A.; Perrone, C.E. Sulfur amino acids in methionine-restricted rats: Hyperhomocysteinemia. Nutrition 2010, 26, 1201-1204. [CrossRef] [PubMed]

21. Elshorbagy, A.K.; Church, C.; Valdivia-Garcia, M.; Smith, A.D.; Refsum, H.; Cox, R. Dietary cystine level affects metabolic rate and glycaemic control in adult mice. J. Nutr. Biochem. 2012, 23, 332-340. [CrossRef] [PubMed]

22. Elshorbagy, A.K.; Jerneren, F.; Scudamore, C.L.; McMurray, F.; Cater, H.; Hough, T.; Cox, R.; Refsum, H. Exploring the Lean Phenotype of Glutathione-Depleted Mice: Thiol, Amino Acid and Fatty Acid Profiles. PLoS ONE 2016, 11, e0163214. [CrossRef] [PubMed]

23. Perrone, C.E.; Mattocks, D.A.; Jarvis-Morar, M.; Plummer, J.D.; Orentreich, N. Methionine restriction effects on mitochondrial biogenesis and aerobic capacity in white adipose tissue, liver, and skeletal muscle of F344 rats. Metabolism 2010, 59, 1000-1011. [CrossRef] [PubMed]

24. Vinknes, K.J.; Dekker, J.M.; Drevon, C.A.; Refsum, H.; Nurk, E.; Nijpels, G.; Stehouwer, C.D.; Teerlink, T.; Tell, G.S.; Nygard, O.; et al. Plasma sulfur amino acids and stearoyl-CoA desaturase activity in two caucasian populations. Prostaglandins Leukot. Essent. Fatty Acids 2013, 89, 297-303. [CrossRef] [PubMed]

25. Vinknes, K.J.; Elshorbagy, A.K.; Nurk, E.; Drevon, C.A.; Gjesdal, C.G.; Tell, G.S.; Nygard, O.; Vollset, S.E.; Refsum, H. Plasma stearoyl-CoA desaturase indices: Association with lifestyle, diet, and body composition. Obesity 2013, 21, E294-E302. [CrossRef] [PubMed] 
26. Warensjo, E.; Ohrvall, M.; Vessby, B. Fatty acid composition and estimated desaturase activities are associated with obesity and lifestyle variables in men and women. Nutr. Metab. Cardiovasc. Dis. 2006, 16, 128-136. [CrossRef] [PubMed]

27. Kim, H.J.; Miyazaki, M.; Ntambi, J.M. Dietary cholesterol opposes PUFA-mediated repression of the stearoyl-CoA desaturase-1 gene by SREBP-1 independent mechanism. J. Lipid Res. 2002, 43, 1750-1757. [CrossRef] [PubMed]

28. Yahagi, N.; Shimano, H.; Hasty, A.H.; Amemiya-Kudo, M.; Okazaki, H.; Tamura, Y.; Iizuka, Y.; Shionoiri, F.; Ohashi, K.; Osuga, J.; et al. A crucial role of sterol regulatory element-binding protein-1 in the regulation of lipogenic gene expression by polyunsaturated fatty acids. J. Biol. Chem. 1999, 274, 35840-35844. [CrossRef] [PubMed]

29. Nordic Council of Ministers. Nordic Nutrition Recommendations 2012: Integrating Nutrition and Physical Activity; Nordisk Ministerråd: Copenhagen, Denmark, 2012.

30. Mansoor, M.A.; Bergmark, C.; Svardal, A.M.; Lonning, P.E.; Ueland, P.M. Redox status and protein binding of plasma homocysteine and other aminothiols in patients with early-onset peripheral vascular disease. Homocysteine and peripheral vascular disease. Arterioscler. Thromb. Vasc. Biol. 1995, 15, 232-240. [CrossRef] [PubMed]

31. Antoniades, C.; Shirodaria, C.; Leeson, P.; Baarholm, O.A.; Van-Assche, T.; Cunnington, C.; Pillai, R.; Ratnatunga, C.; Tousoulis, D.; Stefanadis, C.; et al. MTHFR 677 C $>$ T Polymorphism reveals functional importance for 5-methyltetrahydrofolate, not homocysteine, in regulation of vascular redox state and endothelial function in human atherosclerosis. Circulation 2009, 119, 2507-2515. [CrossRef] [PubMed]

32. Lee, S.G.; Yim, J.; Lim, Y.; Kim, J.H. Validation of a liquid chromatography tandem mass spectrometry method to measure oxidized and reduced forms of glutathione in whole blood and verification in a mouse model as an indicator of oxidative stress. J. Chromatogr. B Anal. Technol. Biomed. Life Sci. 2016, 1019, 45-50. [CrossRef] [PubMed]

33. Glaser, C.; Demmelmair, H.; Koletzko, B. High-throughput analysis of total plasma fatty acid composition with direct in situ transesterification. PLoS ONE 2010, 5, e12045. [CrossRef] [PubMed]

34. Wainwright, P.E.; Leatherdale, S.T.; Dubin, J.A. Advantages of mixed effects models over traditional ANOVA models in developmental studies: A worked example in a mouse model of fetal alcohol syndrome. Dev. Psychobiol. 2007, 49, 664-674. [CrossRef] [PubMed]

35. Raguso, C.A.; Regan, M.M.; Young, V.R. Cysteine kinetics and oxidation at different intakes of methionine and cystine in young adults. Am. J. Clin. Nutr. 2000, 71, 491-499. [CrossRef] [PubMed]

36. Fukagawa, N.K.; Yu, Y.M.; Young, V.R. Methionine and cysteine kinetics at different intakes of methionine and cysteine in elderly men and women. Am. J. Clin. Nutr. 1998, 68, 380-388. [CrossRef] [PubMed]

37. Hiramatsu, T.; Fukagawa, N.K.; Marchini, J.S.; Cortiella, J.; Yu, Y.M.; Chapman, T.E.; Young, V.R. Methionine and cysteine kinetics at different intakes of cystine in healthy adult men. Am. J. Clin. Nutr. 1994, 60, 525-533. [CrossRef] [PubMed]

38. Jones, D.P.; Park, Y.; Gletsu-Miller, N.; Liang, Y.; Yu, T.; Accardi, C.J.; Ziegler, T.R. Dietary sulfur amino acid effects on fasting plasma cysteine/cystine redox potential in humans. Nutrition 2011, 27, 199-205. [CrossRef] [PubMed]

39. Bella, D.L.; Hahn, C.; Stipanuk, M.H. Effects of nonsulfur and sulfur amino acids on the regulation of hepatic enzymes of cysteine metabolism. Am. J. Physiol. 1999, 277, E144-E153. [CrossRef] [PubMed]

40. Bella, D.L.; Hirschberger, L.L.; Hosokawa, Y.; Stipanuk, M.H. Mechanisms involved in the regulation of key enzymes of cysteine metabolism in rat liver in vivo. Am. J. Physiol. 1999, 276, E326-E335. [CrossRef] [PubMed]

41. Hamadeh, M.J.; Hoffer, L.J. Effect of protein restriction on sulfur amino acid catabolism in insulin-dependent diabetes mellitus. Am. J. Physiol. Endocrinol. Metab. 2003, 284, E382-E389. [CrossRef] [PubMed]

42. Ganguly, P.; Alam, S.F. Role of homocysteine in the development of cardiovascular disease. Nutr. J. 2015, 14, 6. [CrossRef] [PubMed]

43. Ingenbleek, Y. Lean Body Mass Harbors Sensing Mechanisms that Allow Safeguarding of Methionine Homeostasis. Nutrients 2017, 9. [CrossRef] [PubMed]

44. Zhang, N. Role of methionine on epigenetic modification of DNA methylation and gene expression in animals. Anim. Nutr. 2018, 4, 11-16. [CrossRef] [PubMed] 
45. Dong, Z.; Sinha, R.; Richie, J.P., Jr. Disease prevention and delayed aging by dietary sulfur amino acid restriction: Translational implications. Ann. N. Y. Acad. Sci. 2018, 1418, 44-55. [CrossRef] [PubMed]

46. Plaisance, E.P.; Greenway, F.L.; Boudreau, A.; Hill, K.L.; Johnson, W.D.; Krajcik, R.A.; Perrone, C.E.; Orentreich, N.; Cefalu, W.T.; Gettys, T.W. Dietary methionine restriction increases fat oxidation in obese adults with metabolic syndrome. J. Clin. Endocrinol. Metab. 2011, 96, E836-E840. [CrossRef] [PubMed]

47. Velliquette, R.A.; Gillies, P.J.; Kris-Etherton, P.M.; Green, J.W.; Zhao, G.; Vanden Heuvel, J.P. Regulation of human stearoyl-CoA desaturase by omega-3 and omega- 6 fatty acids: Implications for the dietary management of elevated serum triglycerides. J. Clin. Lipidol. 2009, 3, 281-288. [CrossRef] [PubMed]

48. Bjermo, H.; Iggman, D.; Kullberg, J.; Dahlman, I.; Johansson, L.; Persson, L.; Berglund, J.; Pulkki, K.; Basu, S.; Uusitupa, M.; et al. Effects of n-6 PUFAs compared with SFAs on liver fat, lipoproteins, and inflammation in abdominal obesity: A randomized controlled trial. Am. J. Clin. Nutr. 2012, 95, 1003-1012. [CrossRef] [PubMed]

49. Warensjo, E.; Riserus, U.; Gustafsson, I.B.; Mohsen, R.; Cederholm, T.; Vessby, B. Effects of saturated and unsaturated fatty acids on estimated desaturase activities during a controlled dietary intervention. Nutr. Metab. Cardiovasc. Dis. 2008, 18, 683-690. [CrossRef] [PubMed]

(C) 2018 by the authors. Licensee MDPI, Basel, Switzerland. This article is an open access article distributed under the terms and conditions of the Creative Commons Attribution (CC BY) license (http:/ / creativecommons.org/licenses/by/4.0/). 